\title{
TITLE:
}

\section{Electrochemical reduction behavior of borosilicate glass in molten $\mathrm{CaCl}$}

$\operatorname{AUTHOR}(\mathrm{S}):$

Katasho, Yumi; Yang, Xiao; Yasuda, Kouji; Nohira, Toshiyuki

\section{CITATION:}

Katasho, Yumi ... [et al]. Electrochemical reduction behavior of borosilicate glass in molten CaCl. Journal of the Electrochemical Society 2016, 163(10): D622-D627

ISSUE DATE:

2016-08-26

URL:

http://hdl.handle.net/2433/234943

\section{RIGHT:}

(c) The Electrochemical Society, Inc. 2016. All rights reserved. Except as provided under U.S. copyright law, this work may not be reproduced, resold, distributed, or modified without the express permission of The Electrochemical Society (ECS). The archival version of this work was published in J. Electrochem. Soc. 2016 volume 163, issue 10, D622-D627.; こ の論文は出版社版でありません。引用の際には出版社版をご確認ご利用ください。; This is not the published version. Please cite only the published version. 
2 Title:

3 Electrochemical Reduction Behavior of Borosilicate Glass in Molten $\mathrm{CaCl}_{2}$

4

5 Authors:

Yumi KATASHO, ${ }^{a}$ Xiao YANG, ${ }^{\text {a }}$ Kouji YASUDA,,${ }^{b, c, *}$ Toshiyuki NOHIRA,, a,*,z

7

Affiliation:

9 anstitute of Advanced Energy, Kyoto University, Gokasho, Uji, Kyoto 611-0011, 10 Japan.

$11{ }^{b}$ Environment, Safety and Health Organization, Kyoto University, Yoshida-

12 hommachi, Sakyo-ku, Kyoto 606-8501, Japan.

13 'Department of Fundamental Energy Science, Graduate School of Energy

14 Science, Kyoto University, Yoshida-hommachi, Sakyo-ku, Kyoto 606-8501, 15 Japan.

16

17

$18 *$ Electrochemistry Society Active Member

19

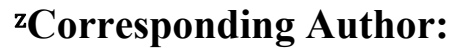

21 nohira.toshiyuki.8r@kyoto-u.ac.jp (T. Nohira) 
Abstract

The electrochemical reduction behavior of borosilicate glass, which is the main component of vitrified radioactive waste, was investigated in molten $\mathrm{CaCl}_{2}$ at $1123 \mathrm{~K}$ to establish a new nuclear waste disposal procedure. Cyclic voltammetry of borosilicate and silica glasses suggested that the reduction of $\mathrm{B}_{2} \mathrm{O}_{3}$ in borosilicate glass occurred at a more positive potential than that of $\mathrm{SiO}_{2}$. X-ray photoelectron spectroscopy confirmed that the $\mathrm{B}_{2} \mathrm{O}_{3}$ component was reduced to $\mathrm{B}$ or a B-Si compound at $0.9 \mathrm{~V}$ vs. $\mathrm{Ca}^{2+} / \mathrm{Ca}$. The reduction products prepared by the potentiostatic electrolysis of borosilicate glass at $0.9 \mathrm{~V}$ had granular morphology and consisted of crystalline $\mathrm{Si}$. The $\mathrm{Al}_{2} \mathrm{O}_{3}$ component was not reduced at $0.9 \mathrm{~V}$ and the $\mathrm{Na}_{2} \mathrm{O}$ component was suggested to be dissolved in molten $\mathrm{CaCl}_{2}$ during electrolysis.

15 Keywords:

16 Molten salt; vitrified radioactive wastes; electrochemical reduction; borosilicate glass 


\section{Introduction}

Nuclear power was responsible for generating more than $11 \%$ of the world's

3 electricity in $2015 .{ }^{1}$ Since the life-cycle of greenhouse gas emissions from nuclear

4 power is much lower than that of other conventional base load energy sources, ${ }^{1}$ nuclear power has the potential to mitigate global warming by replacing fossil fuels in power generation.

On the other hand, nuclear power generation has challenges, particularly in the disposal of radioactive wastes. Currently, high-level nuclear wastes are confined in

9 borosilicate glass to prepare them for ultimate disposal, i.e., they are isolated until they lose enough radioactivity in a process called deep geological disposal. A typical composition of the vitrified waste is $43-53 \mathrm{wt} \% \mathrm{SiO}_{2}, 7-17 \mathrm{wt} \% \mathrm{~B}_{2} \mathrm{O}_{3}, 3-5 \mathrm{wt} \% \mathrm{Al}_{2} \mathrm{O}_{3}$, 6-24 wt $\% \mathrm{Na}_{2} \mathrm{O}$, and $\leqq 25-35 \mathrm{wt}^{2} \%$ nuclear wastes. ${ }^{2}$ By 2000 , the vitrification facilities of the French company COGEMA (presently Areva) had produced over 10,000 canisters containing about 4,000 tons of vitrified high-level waste. ${ }^{3}$ Globally, a significant amount of radioactive wastes have been produced in the past and even

16 larger amounts will be produced in the future. The International Atomic Energy 17 Agency (IAEA) reported that the total amount of spent fuel generated worldwide was about 276,000 tHM (tons of heavy metal) at the end of $2004 .^{4}$ Among them, 90,000 tHM had been reprocessed and 186,000 tHM were being stored for reprocessing. ${ }^{4}$ However, in many countries including Japan, the places for ultimate disposal have not

21 been determined yet. Among the difficulties in earthquake prone nations like Japan is 22 finding stable geological layers.

To address this situation, a new disposal process has been proposed in Japan:

24 Long-lived fission products (LLFPs) such as ${ }^{135} \mathrm{Cs},{ }^{79} \mathrm{Se},{ }^{93} \mathrm{Zr}$, and ${ }^{107} \mathrm{Pd}$, whose half25 lives are 2.3 million, 327 thousand, 1.53 million, and 6.5 million years, respectively, 26 in the high-level nuclear waste are separated and converted into short-lived or stable 
1 nuclides by nuclear transmutation. ${ }^{5}$ Since the amount of radioactive wastes is

2 significantly decreased, the need to prepare ultimate disposal locations is eliminated.

3 Moreover, some elements found in the waste, e.g., platinum group metals, are

4 expected to be utilized for various applications such as automobile catalysts and fuel 5 cell catalysts.

The LLFPs in vitrified wastes must first be recovered and then separated from each other before the transmutation process. Since the vitrified wastes are originally prepared to confine the LLFPs stably for a long time, the recovery of the LLFPs is challenging. First, a pretreatment process that can destroy the glass structure of the vitrified wastes is required. While glass can be dissolved by hydrofluoric acid, wet

11 processes using hydrofluoric acid cannot be used in pretreatment without producing a large amount of secondary radioactive waste. In contrast, dry processes, although not

13 studied so far, have the potential advantages of decreasing the amount of secondary 14 wastes and providing a high processing rate. Among several conceivable dry 15 processes, electrochemical reduction in molten salt is worth investigating because electrochemical reductions of solid metal oxides including $\mathrm{SiO}_{2}$ in molten salts have already been established. ${ }^{6,7}$ Furthermore, the behaviors of many fission products (FPs) in molten salts have been widely studied in the field of nuclear fuel reprocessing.

19 Thus, it is possible to design a separation process for LLFPs in molten salts that 20 follows a pretreatment process relying on electrochemical reduction.

21 To this day, many studies have been conducted on the electrochemical reduction of solid metal oxides in $\mathrm{CaCl}_{2}$-based molten salts for the development of new 23 production processes for valuable materials. ${ }^{6,7}$ Chen et al ${ }^{8}$ firstly reported the direct 24 electrochemical reduction of $\mathrm{TiO}_{2}$ to $\mathrm{Ti}$ in molten $\mathrm{CaCl}_{2}$. After their report, 25 electrochemical reduction of various ionic metal oxides have been studied in molten 26 salts on a laboratory scale (e.g. $\mathrm{Ti}^{8}, \mathrm{Cr}^{9}, \mathrm{Ce}^{10}, \mathrm{Nb}^{11}, \mathrm{Ta}^{12}, \mathrm{~W}^{13}, \mathrm{Ni}^{14}, \mathrm{Zr}^{15}, \mathrm{Dy}^{16}, \mathrm{U}^{17}$ ). 
1 In addition to ionic oxides, electrochemical reduction of covalent oxide $\mathrm{SiO}_{2}$ in

2 molten $\mathrm{CaCl}_{2}$ was also reported. ${ }^{18}$ Since $\mathrm{SiO}_{2}$ is an insulating material even at high

3 temperatures, the reduction requires a special structure of electrodes called

4 "contacting electrode". The $\mathrm{SiO}_{2}$ contacting electrode is prepared by direct contact of

5 the conducting material, typically a molybdenum wire, to an $\mathrm{SiO}_{2}$ plate. ${ }^{18}$ The

6 reduction starts at the three-phase zone consisting of an oxide, a conductor, and a

7 molten salt. The reaction zone spreads throughout the $\mathrm{SiO}_{2}$ because the produced

8 silicon has a high electric conductivity at high temperatures that generates additional

9 electron pathways accompanied by a penetration of the molten salt into the porous $\mathrm{Si}$

10 layer. $^{19}$

Cathode: $\mathrm{SiO}_{2}(s)+4 \mathrm{e}^{-} \rightarrow \mathrm{Si}(s)+2 \mathrm{O}^{2-}$

$$
\text { Anode }: \mathrm{C}(s)+x \mathrm{O}^{2-} \rightarrow \mathrm{CO}_{x}(g)+2 x \mathrm{e}^{-}
$$

13 Our group and other groups have proposed to apply the above reactions for the 14 production of solar grade silicon, ${ }^{19-38}$ the preparation of silicon nanowires, ${ }^{25,39,40}$ and 15 the preparation of negative electrode material for lithium ion batteries. ${ }^{41}$ In these electrochemical methods, $\mathrm{CaCl}_{2}$-based molten salts have been typically used as the electrolytic bath because of their high solubility of $\mathrm{O}^{2-}$ ions. ${ }^{42}$

The current state of the research concerning direct electrolytic reduction of other oxide components typically found in vitrified wastes is outlined below. For the second largest waste component $-\mathrm{B}_{2} \mathrm{O}_{3}-$ the direct electrochemical reduction in molten salts has not been reported. Incidentally, the production of elemental boron by molten salt electrolysis has been studied for almost one century. B(III) ions prepared by the

23 dissolution of $\mathrm{B}_{2} \mathrm{O}_{3}$ have been reduced to elemental boron in a single step in $\mathrm{KF}, \mathrm{KCl}$, $24 \mathrm{KCl}-\mathrm{KF}, \mathrm{NaCl}-\mathrm{KCl}$, and NaCl-KCl-NaF molten salts. ${ }^{43}$ Also for alkali oxides such as $25 \mathrm{Na}_{2} \mathrm{O}$, no direct electrochemical reduction study has been reported. With respect to $26 \mathrm{Al}_{2} \mathrm{O}_{3}$, Yan and Fray investigated the electrochemical reduction behavior in $\mathrm{CaCl}_{2}-$ 
1 based molten salts and reported potential- $\mathrm{pO}^{2-}$ diagrams. ${ }^{45}$ As previously reported,

2 Al-rich Al-Ca alloys have been obtained with calcium aluminates as intermediate 3 reduction products.

4 In this study, we investigated the electrochemical reduction of borosilicate glass

5 in molten $\mathrm{CaCl}_{2}$ with the aim of developing a new pretreatment method for the

6 vitrified radioactive wastes. Since the reduction behavior of the actual vitrified

7 radioactive wastes is expected to be complicated, borosilicate glass was selected as

8 the study object. Specifically, Pyrex ${ }^{\circledR}$ glass was chosen from among the many kinds

9 of borosilicate glass because it is the most typical one. The electrochemical behavior

10 of Pyrex ${ }^{\circledR}$ glass was studied by cyclic voltammetry and the results were compared to

11 those of $\mathrm{SiO}_{2}$. Here, glass-seal electrodes, ${ }^{24,30,39,44}$ which give good reproducibility for

12 the geometry of the glass/conductor/ $\mathrm{CaCl}_{2}$ three-phase zone, were employed.

13 Potentiostatic electrolysis was conducted at several selected potentials to prepare the 14 samples for instrumental analysis. Based on these results, the electrochemical 15 reduction behavior of borosilicate glass was determined.

\section{Experimental}

Figure 1 shows a schematic of the experimental apparatus. $500 \mathrm{~g}$ of $\mathrm{CaCl}_{2}(>$ 95.0 \%, Wako Pure Chemical Industries, Ltd.) crushed in a mortar was placed in an alumina crucible (outer diameter: $90 \mathrm{~mm}$, height: $140 \mathrm{~mm}$, purity 99\%, As One Corp.)

21 and put in an open dry chamber (HRW-60AR, Daikin Co. Ltd.). Then, the $\mathrm{CaCl}_{2}$ was dried at $453 \mathrm{~K}$ in a vacuumed oven for more than $72 \mathrm{~h}$, transferred to a quartz glass

23 vessel, and vacuumed at $773 \mathrm{~K}$ for $24 \mathrm{~h}$ to further remove moisture. The subsequent 24 electrochemical experiments were conducted inside the quartz glass vessel at $1123 \mathrm{~K}$ under a dry Ar atmosphere. 
Electrochemical measurements and potentiostatic electrolysis were conducted

2 with a three-electrode method using an electrochemical measurement system (HZ-

3 3000, Hokuto Denko Corp.). Glass-seal electrodes (Fig. 2a) and wire-wound

4 electrodes (Fig. 2b) were used as the working electrodes. In the glass-seal electrodes,

5 a tungsten rod ( $>99.95 \%$, diameter: $2.0 \mathrm{~mm}$, Nilaco corp.) was sealed in a

6 borosilicate glass tube $\left(\mathrm{Pyrex}^{\circledR}, \mathrm{SiO}_{2} 80.8 \mathrm{wt} \%, \mathrm{~B}_{2} \mathrm{O}_{3} 12.5 \mathrm{wt} \%, \mathrm{Al}_{2} \mathrm{O}_{3} 2.3 \mathrm{wt} \%, \mathrm{Na}_{2} \mathrm{O}\right.$

$74.0 \mathrm{wt} \%, \mathrm{~K}_{2} \mathrm{O} 0.4 \mathrm{wt} \%$, o.d. $8 \mathrm{~mm}$ ) or a silica $\left(\mathrm{SiO}_{2}\right)$ glass tube (o.d. $\left.6 \mathrm{~mm}\right) . \mathrm{In}$ the

8 wire-wound electrodes, a borosilicate glass plate (Tempex ${ }^{\circledR}, \mathrm{SiO}_{2} 81 \mathrm{wt} \%, \mathrm{~B}_{2} \mathrm{O}_{3} 13$

$\left.9 \mathrm{wt} \%, \mathrm{Al}_{2} \mathrm{O}_{3} 2 \mathrm{wt} \%, \mathrm{Na}_{2} \mathrm{O} 3.3 \mathrm{wt} \%, \mathrm{~K}_{2} \mathrm{O} 0.7 \mathrm{wt} \%, 5 \mathrm{~mm} \times 15 \mathrm{~mm} \times 1.1 \mathrm{~mm}\right)$ or a

10 silica glass plate $(5 \mathrm{~mm} \times 15 \mathrm{~mm} \times 1 \mathrm{~mm})$ was wound by a Mo wire (diam. $0.2 \mathrm{~mm}$, >

$1199.95 \%$, Nilaco Corp.). ${ }^{37}$ The counter electrode was a graphite square rod $(4 \mathrm{~mm} \times 4$

$12 \mathrm{~mm} \times 50 \mathrm{~mm}$ ) and the reference electrode was an $\mathrm{Ag}^{+} / \mathrm{Ag}$ electrode. ${ }^{36}$ All potentials

13 in the present paper have been calibrated by the redox potential of $\mathrm{Ca}$, which was

14 obtained by electrodepositing calcium metal on a Mo wire electrode (diam.1 mm). A

15 chromel-alumel thermocouple inserted in an alumina tube was used for the 16 temperature control.

17 Following potentiostatic electrolysis, the glass-sealed electrodes were rinsed with

18 distilled water to remove residual salts, dried at room temperature, and cut by a

19 diamond cutter into $\sim 5 \mathrm{~mm}$ long sections. The prepared samples were evaluated using

20 an optical digital microscope (Dino Lite PRO Polarizer DILITE30 AM-413ZT, Sanko

21 Co., Ltd.) and a scanning electron microscope (SEM; VE-8800, Keyence Corp.). They

22 were also characterized by energy dispersive X-ray spectroscopy (EDX; EDAX

23 Genesis APEX2, AMETEK Co. Ltd.), X-ray diffractometry (XRD; Ultima IV, Cu-Ka

24 line, Rigaku Corp.), and X-ray photoelectron spectroscopy (XPS, JPS-9010MC, JEOL

25 Ltd.). For the XPS measurement, potentiostatic electrolysis was conducted at $0.9 \mathrm{~V}$ vs.

$26 \mathrm{Ca}^{2+} / \mathrm{Ca}$ for 60 minutes, and the samples were rinsed with distilled water, $8 \% \mathrm{HCl}$ 
1 aqueous solution, and $10 \% \mathrm{NaOH}$ aqueous solution. The powdery products recovered

2 from the reduced glass-sealed electrodes were fixed evenly on carbon tape and then

3 etched by Ar ion irradiation to remove the natural oxide from the surface. The spectra

4 were calibrated by the $\mathrm{C} 1 \mathrm{~s}$ peak at $284.8 \mathrm{eV}$ for the reduced sample and by the Si-O

5 peak at $103.3 \mathrm{eV}$ for the unreduced sample.

6

\section{Results and Discussion}

3.1 Thermodynamic calculations

Prior to the experiments, the reactions were estimated by Ellingham diagrams for oxides and chlorides. Figure 3(a) shows the Ellingham diagram for the oxides in the reaction system $\left(\mathrm{MO}_{x}, \mathrm{M}=\mathrm{Si}, \mathrm{B}, \mathrm{Al}, \mathrm{Na}, \mathrm{K}\right.$, and $\left.\mathrm{Ca}\right)$. Among the components of borosilicate glass, $\mathrm{K}_{2} \mathrm{O}, \mathrm{Na}_{2} \mathrm{O}$, and $\mathrm{B}_{2} \mathrm{O}_{3}$ are less stable than $\mathrm{SiO}_{2}$. These oxides are expected to be reduced at more positive potentials than the reduction potential of $\mathrm{SiO}_{2}$ $\left(1.25 \mathrm{~V}^{37}\right)$. On the other hand, the diagram shows that the reduction of $\mathrm{Al}_{2} \mathrm{O}_{3}$ proceeds at a more negative potential. In the case of pure $\mathrm{Al}_{2} \mathrm{O}_{3}$, the formation of calcium aluminate depended on the conditions. ${ }^{45}$ Moreover, there is a possibility of the formation of complex oxides such as $\mathrm{CaSiO}_{3}$ and $\mathrm{CaB}_{2} \mathrm{O}_{4}$. Since the stability of these oxides in molten $\mathrm{CaCl}_{2}$ depends on the concentration of $\mathrm{O}^{2-}$ ion, the construction of $E-\mathrm{pO}^{2-}$ diagram for boron is also required for the detailed discussion in the same manner with the reduction of $\mathrm{SiO}_{2} .^{36}$ The construction of $E-p \mathrm{O}^{2-}$ diagrams will be reported in a separate full paper.

Figure 3(b) shows the Ellingham diagram for the related chlorides $\left(\mathrm{MCl}_{x}, \mathrm{M}=\mathrm{Si}\right.$, $\mathrm{B}, \mathrm{Al}, \mathrm{Na}, \mathrm{K}$, and $\mathrm{Ca}) .{ }^{46}$ While the Gibbs formation energies for $\mathrm{Na}_{2} \mathrm{O}$ and $\mathrm{K}_{2} \mathrm{O}$ are far more positive than that of $\mathrm{CaO}$, those for $\mathrm{NaCl}$ and $\mathrm{KCl}$ are as negative as that for $\mathrm{CaCl}_{2}$. Thus, as outlined below by Equations 3 and 4, the reaction of $\mathrm{Na}_{2} \mathrm{O}$ or $\mathrm{K}_{2} \mathrm{O}$ with molten $\mathrm{CaCl}_{2}$ is thermodynamically favorable. 


$$
\begin{array}{r}
\mathrm{Na}_{2} \mathrm{O}(s)+\mathrm{CaCl}_{2}(l)=\mathrm{CaO}(s)+2 \mathrm{NaCl}(l) \\
\Delta G^{\mathrm{o}}{ }_{1123 \mathrm{~K}}=-246.5 \mathrm{~kJ} \mathrm{~mol}^{-1}(\text { Ref. } 46) \\
\mathrm{K}_{2} \mathrm{O}(s)+\mathrm{CaCl}_{2}(l)=\mathrm{CaO}(s)+2 \mathrm{KCl}(l) \\
\Delta G^{\mathrm{o}}{ }_{1123 \mathrm{~K}}=-347.7 \mathrm{~kJ} \mathrm{~mol}^{-1}(\text { Ref. } 46)
\end{array}
$$

2

3 Namely, the components of $\mathrm{Na}_{2} \mathrm{O}$ and $\mathrm{K}_{2} \mathrm{O}$ in the glass are expected to dissolve to

4 molten salt as $\mathrm{NaCl}$ and $\mathrm{KCl}$. On the contrary, for $\mathrm{SiO}_{2}, \mathrm{~B}_{2} \mathrm{O}_{3}$, and $\mathrm{Al}_{2} \mathrm{O}_{3}$, the 5 reactions with molten $\mathrm{CaCl}_{2}$ are unfavorable, as seen below in Equations 5-7.

$$
\begin{gathered}
\mathrm{SiO}_{2}(s)+2 \mathrm{CaCl}_{2}(l)=2 \mathrm{CaO}(s)+\mathrm{SiCl}_{4}(g) \\
\Delta G^{\mathrm{o}}{ }_{1123 \mathrm{~K}}=409.5 \mathrm{~kJ} \mathrm{~mol}^{-1}(\text { Ref. } 46) \\
\mathrm{B}_{2} \mathrm{O}_{3}(l)+3 \mathrm{CaCl}_{2}(l)=3 \mathrm{CaO}(s)+2 \mathrm{BCl}_{3}(g) \\
\Delta G^{\mathrm{o}}{ }_{1123 \mathrm{~K}}=623.2 \mathrm{~kJ} \mathrm{~mol}^{-1}(\text { Ref. } 46) \\
\mathrm{Al}_{2} \mathrm{O}_{3}(s)+3 \mathrm{CaCl}_{2}(l)=3 \mathrm{CaO}(s)+2 \mathrm{AlCl}_{3}(g) \\
\Delta G^{\mathrm{o}}{ }_{1123 \mathrm{~K}}=666.2 \mathrm{~kJ} \mathrm{~mol}^{-1}(\text { Ref. } 46)
\end{gathered}
$$

6

3.2 Cyclic voltammetry

Fig. 4 (a) and (b) show the cyclic voltammograms for sealed borosilicate glass and silica glass electrodes in molten $\mathrm{CaCl}_{2}$ at $1123 \mathrm{~K}$, respectively. The voltammograms were recorded for five consecutive cycles. The apparent current density is expressed with respect to the bottom area (the exposed area) of the tungsten rod. In the voltammogram for borosilicate glass (Fig. 4 (a)), a small cathodic current is observed from $1.8 \mathrm{~V}$ vs. $\mathrm{Ca}^{2+} / \mathrm{Ca}$. Since the potential is more positive than the $\mathrm{SiO}_{2}$ reduction potential (Fig. 4(b)), this cathodic current is interpreted as the reduction of some oxides that are less stable than $\mathrm{SiO}_{2}$. A larger cathodic current flows from $1.3 \mathrm{~V}$, which corresponds to the reduction of $\mathrm{SiO}_{2}$ to $\mathrm{Si}^{37}$ Moreover, a sharp increase of 
1 cathodic current at $0.5 \mathrm{~V}$ is explained by the formation of Si-Ca alloys. ${ }^{28,37}$ After the

2 reversal of scan direction to positive, an anodic current peak is observed at $0.7 \mathrm{~V}$,

3 which corresponds to the dissolution of $\mathrm{Ca}$ from Si-Ca alloys. Then, anodic current

4 rising from $1.3 \mathrm{~V}$ is regarded as the reoxidation of $\mathrm{Si}$ to $\mathrm{SiO}_{2}$. Finally, a small anodic

5 current is observed from $1.8 \mathrm{~V}$. This current is the reoxidation of reduction product

6 which has been produced in the negative scan.

In both cyclic volrammograms for borosilicate and silica glass, the currents

8 increase as the cycles are repeated. For pure $\mathrm{SiO}_{2}$, this behavior has been explained by

9 the increase of the reaction zone due to the formation of conductive Si from insulating

$10 \mathrm{SiO}_{2}{ }^{19}$ A similar mechanism is possible for the reduction of borosilicate glass.

3.3 Potentiostatic electrolysis

To confirm the reduction reaction results, potentiostatic electrolysis was conducted using borosilicate glass-sealed electrodes at $0.6 \mathrm{~V}(\mathrm{~B}-1), 0.9 \mathrm{~V}(\mathrm{~B}-2)$, and $1.4 \mathrm{~V}(\mathrm{~B}-3)$, and silica glass-sealed electrodes at $0.6 \mathrm{~V}(\mathrm{~S}-1), 0.9 \mathrm{~V}(\mathrm{~S}-2)$, and $1.4 \mathrm{~V}$ (S-3) for 30 minutes in molten $\mathrm{CaCl}_{2}$ at $1123 \mathrm{~K}$. Figure 5 shows current-time curves during the potentiostatic electrolysis and Figure 6 shows the microscope images of the reduced glass-sealed electrodes. In the electrolysis at $0.9 \mathrm{~V}$ and $0.6 \mathrm{~V}$, the reduction currents for borosilicate glass are larger than those for silica glass. In addition, the current oscillations suggest the periodic change of three phase zone, which might have

21 occurred by the generation of $\mathrm{H}_{2}$ by reduction of hydroxyl groups in the glass. On the other hand, in Fig. 6(a), the reduced area looks smaller for borosilicate glass compared to that of silica glass. This outcome is confirmed by Fig. 6(b), where the surface reduction progressed to the side of the tube in the case of silica glass at $0.6 \mathrm{~V}$.

25 These results indicate the smaller surface reaction rate for borosilicate glass. The observed larger current and slower surface reaction for borosilicate glass are 
1 explained by its faster inner direction progress As shown in the cross-sectional image

2 for sample B-2 (Fig. 6(c)), the depth of the reduced portion for borosilicate glass is

3 almost the same length as the reduced portion on the surface. At $1.4 \mathrm{~V}$, the observed

4 current is larger for borosilicate glass compared to that of silica glass, which is

5 consistent with the cyclic voltammetry results. However, the current value is much

6 smaller compared to the electrolysis at more negative potentials. Since noticeable

7 change is not observed in the microscope images, the reduction did not proceed in

8 bulk for either borosilicate glass or silica glass.

9

\subsection{Characterization of the products}

Figure 7 shows the XRD patterns for the reduced (a) borosilicate glass plate and (b) silica glass plate at $0.9 \mathrm{~V}$ in molten $\mathrm{CaCl}_{2}$ at $1123 \mathrm{~K}$. The formation of crystalline silicon was confirmed for both samples. Considering the full widths at half maximum for the peaks in two patterns, the crystallinity of produced silicon obtained from borosilicate glass was lower than that from silica glass.

Figure 8 shows XPS spectra for (a) B $1 s$ and (b) Si $2 p$ before and after the reduction of borosilicate samples. In Fig. 8 (a), a weakened B-O peak and a strengthened B-B or B-Si peak are observed for the reduced sample, which confirm the reduction of boron oxide to its metallic state. In the same manner, the reduction of silicon oxide to its metallic state is confirmed in Fig. 8(b), agreeing with the XRD analysis.

Figure 9 shows (a) a SEM image of the unreduced borosilicate glass, (b) SEM image and EDX mapping results for the reduction products obtained by the electrolysis at $0.9 \mathrm{~V}$ for 30 minutes, and (c) the EDX analysis results for the two specified points in the figure. Following electrolytic reduction, the flat morphology of the original borosilicate glass changes to a granular one with a diameter of $1 \sim 10 \mu \mathrm{m}$. 
1 The different morphology from the previously reported result for silica glass, in which

2 Si wires or Si columns with a diameter $\sim 1 \mu \mathrm{m}$ were observed ${ }^{18,19}$, might be attributed

3 to the presence of boron oxide and aluminum oxide. As shown from EDX mapping

4 results, the areas with high $\mathrm{O}$ concentration always contain $\mathrm{Al}, \mathrm{Ca}$, and $\mathrm{Cl}$, suggesting

5 that aluminum oxide is not reduced at $0.9 \mathrm{~V}$, and that calcium aluminate forms via the reaction with $\mathrm{CaO}$ in the molten salt. This explanation is consistent with the potential$\mathrm{pO}^{2-}$ diagram for the Al-Ca-O-Cl system. ${ }^{45}$ Here, the detected $\mathrm{Cl}$ is likely due to the

8 complex compounds with calcium aluminate and $\mathrm{CaCl}_{2}$. As for $\mathrm{Na}$ content, the

9 dissolution of $\mathrm{Na}_{2} \mathrm{O}$ into molten $\mathrm{CaCl}_{2}$ is suggested because the $\mathrm{Na}$ concentration

10 largely decreased both in the reduced area (point 1) and unreduced area (point 2)

11 relative to the original value. Incidentally, the concentration of $\mathrm{K}$ in the original

12 borosilicate glass was below the detection limit of EDX. Considering the

13 thermodynamic calculation and the chemical similarity with $\mathrm{Na}$, the behavior of $\mathrm{K}$ is 14 believed to be the same as that of $\mathrm{Na}$.

\section{Conclusions}

The electrochemical reduction behavior of borosilicate glass, whose components were 80.8 wt $\% \mathrm{SiO}_{2}, 12.5 \mathrm{wt} \% \mathrm{~B}_{2} \mathrm{O}_{3}, 2.3 \mathrm{wt} \% \mathrm{Al}_{2} \mathrm{O}_{3}, 4.0 \mathrm{wt} \% \mathrm{Na}_{2} \mathrm{O}$, and $0.4 \mathrm{wt} \%$ $\mathrm{K}_{2} \mathrm{O}$, was investigated in molten $\mathrm{CaCl}_{2}$ at $1123 \mathrm{~K}$. Based on cyclic voltammogram comparisons between borosilicate and silica glasses, the reduction of oxides other

21 than $\mathrm{SiO}_{2}$ was determined for borosilicate glass. From the Ellingham diagrams for oxides and chlorides, $\mathrm{B}_{2} \mathrm{O}_{3}$ was expected to be reduced at a more positive potential

23 than $\mathrm{SiO}_{2}$. In the potentiostatic electrolysis at $0.6 \mathrm{~V}\left(\mathrm{vs} . \mathrm{Ca}^{2+} / \mathrm{Ca}\right.$ ) and $0.9 \mathrm{~V}$, the 24 reduction currents were larger for borosilicate glass compared to those of silica glass.

25 The larger currents were explained by the faster reaction toward the inner glass, though the reduction rate in the surface direction was smaller than that of silica glass. 
1 The reduction of $\mathrm{SiO}_{2}$ to crystalline $\mathrm{Si}$ and the reduction of $\mathrm{B}_{2} \mathrm{O}_{3}$ to $\mathrm{B}$ or $\mathrm{B}-\mathrm{Si}$

2 compound were confirmed by XRD and XPS analyses. The granular morphology with

$3 \quad 1 \sim 10 \mu \mathrm{m}$ diameter was observed in the reduced area by SEM and the main component

4 of granules was $\mathrm{Si}$. According to the EDX analysis, $\mathrm{Al}_{2} \mathrm{O}_{3}$ was not reduced and

5 calcium aluminate was formed. The EDX results suggested that the $\mathrm{Na}_{2} \mathrm{O}$ component

6 dissolved into the molten salt during electrolysis. The behavior of the $\mathrm{K}_{2} \mathrm{O}$ component

7 was considered to be the same as that of $\mathrm{Na}_{2} \mathrm{O}$, although the analysis could not be

8 completed because of its low concentration.

9

Acknowledgments

11 This work was partly funded by ImPACT Program of Council for Science,

12 Technology and Innovation (Cabinet Office, Government of Japan).

13

14

15

16 
1. Intergovernmental Panel on Climate Change. Working Group III Climate Change

3 2014: Mitigation of climate change. Annex III: Technology-specific cost and

4 performance parameters.

5 http://report.mitigation2014.org/report/ipcc_wg3_ar5_annex-iii.pdf.

6 2. M. I. Ojovan and W. E. Lee, Metall. Mater. Trans. A, 42, 837 (2011).

8 pub.iaea.org/MTCD/publications/PDF/te_1467_web.pdf.

9 4. IAEA-TECDOC-1532, Operation and Maintenance of Spent Fuel Storage and

10 Transportation Casks/Containers http://www-

11 pub.iaea.org/MTCD/publications/PDF/te_1532_web.pdf.

12 5. Impulsing Paradigm Change through Disruptive Technologies Program. Reduction

13 and Resource Recycle of High Level Radioactive Wastes with Nuclear Transmutation.

$14 \mathrm{http} / / / \mathrm{www} . j s t . g o . j p / i m p a c t / e n /$ program08.html.

15 6. W. Xiao and D. Wang, Chem. Soc. Rev., 43, 3215 (2014).

16 7. A. M. Abdelkader, K. T. Kilby, A. Cox, and D. J. Fray, Chem. Rev. (Washington, 17 DC, U. S.), 113, 2863 (2013).

18 8. G. Z. Chen, D. J. Fray, and T. W. Farthing, Nature (London), 407, 361 (2000).

19 9. C. Schwandt and D. J. Fray, Z. Naturforsch. Z. Naturforsch., A: Phys. Sci. , 62, 655 20 (2007).

21 10. B. Claux, J. Serp, and J. Fouletier, Electrochim. Acta, 56, 2771 (2011).

22 11. X. Y. Yan and D. J. Fray, Metall. Mater. Trans. B, 33B, 685 (2002).

23 12. Q. Song, Q. Xu, X. Kang, J. Du, and Z. Xi, J. Alloys Compd., 490, 241 (2010).

24 13. M. Erdoğan and I. Karakaya, Metall. Mater. Trans. B, 41B, 798 (2010).

25 14. X. Y. Yan and D. J. Fray, Miner. Process. Extr. Metall. Rev., 116, 17 (2007). 
1 15. A. M. Abdelkader, A. Daher, R. A. Abdelkareem, and E. El-Kashif, Metall. Mater.

2 Trans. B, 38B, 35 (2007).

3 16. P. Kim, H. Xie, Y. Zhai, X. Zou, and X. Lang, J. Appl. Electrochem., 42, 257

4 (2012).

5 17. Y. Sakamura, M. Kurata, and T. Inoue, J. Electrochem. Soc., 153, D31 (2006).

6 18. T. Nohira, K. Yasuda, and Y. Ito, Nat. Mater., 2, 397 (2003).

19. K. Yasuda, T. Nohira, K. Amezawa, Y. H. Ogata, and Y. Ito, J. Electrochem. Soc.,

$8 \quad$ 152, D69 (2005).

9 20. J. Cai, X. Luo, G. M. Haarberg, O. E. Kongsteinc, and S. Wang, J. Electrochem.

10 Soc., 159, D155 (2012).

11 21. S. K. Cho, F. R. F. Fan, and A. J. Bard, Angew. Chem. Int. Ed., 51, 12740 (2012).

12 22. J. Eimutis, A. Cox, and D. J. Fray, Electrochim. Acta, 68, 123 (2012).

13 23. E. Ergül, İ. Karakaya, and M. Erdoğan, J. Alloys Compd., 509, 899 (2011).

14 24. X. Jin, P. Gao, D. Wang, X. Hu, and G. Z. Chen, Angew. Chem. Int. Ed., 43, 733

15 (2004).

16 25. Y. Nishimura, T. Nohira, K. Kobayashi, and R. Hagiwara, J. Electrochem. Soc., $17 \quad \mathbf{1 5 8}$, E55 (2011).

18 26. T. Nohira, N. Kani, T. Tsuda, and R. Hagiwara, ECS Trans., 5, 239 (2009).

19 27. T. Oishi, M. Watanabe, K. Koyama, M. Tanaka, and K. Saegusa, J. Electrochem. 20 Soc., 158, E93 (2011).

21 28. T. Toba, K. Yasuda, T. Nohira, X. Yang, R. Hagiwara, K. Ichitsubo, K. Masuda, 22 and T. Homma, Electrochemistry, 81, 559 (2013).

23 29. W. Xiao, X. Jin, and G. Z. Chen, J. Mat. Chem. A, 1, 10243 (2013).

24 30. W. Xiao, X. Jin, Y. Deng, D. Wang, and G. Z. Chen, J. Electroanal. Chem., 639, $25130(2010)$. 
1 31. W. Xiao, X. Jin, Y. Deng, D. Wang, X. Hu, and G. Z. Chen, ChemPhysChem, 7,

$21750(2006)$.

3 32. W. Xiao, X. Wang, H. Yin, H. Zhu, X. Mao, and D. Wnag, RSC Adv., 2, 7588

4 (2012).

5 33. X. Yang, K. Yasuda, T. Nohira, R. Hagiwara, and T. Homma, J. Electrochem.

6 Soc., 161, D3116(2014).

7 34. X. Yang, K. Yasuda, T. Nohira, R. Hagiwara, and T. Homma, Metall. Mater.

8 Trans. B, 45B, 1337 (2014).

9 35. K. Yasuda, T. Nohira, R. Hagiwara, and Y. H. Ogata, Electrochim. Acta, 53, 106

10 (2007).

11 36. K. Yasuda, T. Nohira, R. Hagiwara, and Y. H. Ogata, J. Electrochem. Soc., 154, 12 E95 (2007).

13 37. K. Yasuda, T. Nohira, and Y. Ito, Phys. Chem. Solids, 66, 443 (2005).

14 38. K. Yasuda, T. Nohira, K. Kobayashi, N. Kani, T. Tsuda, and R. Hagiwara, Energy

15 Technol., 1, 245 (2013).

16 39. J. Yang, S. Lu, S. Kan, X. Zhang, and J. Du, Chem. Commun. (Cambridge, U. K.), 173273 (2009).

18 40. J. Zhao, J. Li, P. Ying, W. Zhang, L. Meng, and C. Li, Chem. Commun.

19 (Cambridge, U. K.), 49, 4477 (2013).

20 41. H. Nishihara, T. Suzuki, H. Itoi, B. An, S. Iwamura, R. Berenguer, and T. Kyotani, $21 \quad$ Nanoscale, 6, 10574 (2014).

22 42. P. D. Ferro, B. Mishra, D. L. Olson, and W. A. Averill, Waste Manage. (Oxford, 23 U. K.), 17, 451 (1998).

24 43. J. Zhou and P. Bai, Asia Pac. J. Chem. Eng., 10, 325 (2015).

25 44. P. Gao, X. Jin, D. Wang, X. Hu, and G. Z. Chen, J. Electroanal. Chem., 579, 321 26 (2005). 
$1 \quad$ 45. X. Y. Yan and D. J. Fray, J. Appl. Electrochem., 39, 1349 (2009).

2 46. NIST-JANAF Thermochemical Tables. http://kinetics.nist.gov/janaf/. 3 


\section{$\underline{\text { Figures captions }}$}

3

Fig. 1 Schematic of the experimental apparatus. (A) Working electrode, (B) graphite counter electrode, (C) $\mathrm{Ag}^{+} / \mathrm{Ag}$ reference electrode, and (D) thermocouple.

Fig. 2 Photographs of (a-1) the side view and (a-2) the cross-sectional view of a glass-seal electrode and (b) a wire-wound electrode.

Fig. 3 Ellingham diagrams for selected (a) oxides and (b) chlorides ${ }^{46}$.

Fig. 4 Cyclic voltammograms for sealed (a) borosilicate and (b) silica glass electrodes in molten $\mathrm{CaCl}_{2}$ at $1123 \mathrm{~K}$. Scan rate: $100 \mathrm{mV} \mathrm{s}^{-1}$.

Fig. 5 Current-time curves during the potentiostatic electrolysis of the sealed borosilicate glass electrodes at (B-1) $0.6 \mathrm{~V}$, (B-2) $0.9 \mathrm{~V}$, and (B-3) $1.4 \mathrm{~V}$ and the sealed silica glass electrodes at (S-1) $0.6 \mathrm{~V}$ and (S-2) $0.9 \mathrm{~V}$ vs. $\mathrm{Ca}^{2+} / \mathrm{Ca}$ for 30 minutes in molten $\mathrm{CaCl}_{2}$ at $1123 \mathrm{~K}$.

Fig. 6 (a) Microscope images of the sealed glass electrodes following potentiostatic electrolysis at $0.6 \mathrm{~V}, 0.9 \mathrm{~V}$, and $1.4 \mathrm{~V}$ vs. $\mathrm{Ca}^{2+} / \mathrm{Ca}$ for 30 minutes in molten $\mathrm{CaCl}_{2}$ at $1123 \mathrm{~K}$. White circle shows the boundary between the tungsten rod and the glass. (b) A surface side view of sample S1. (b) A cross-sectional view of sample B-2.

Fig. 7 XRD patterns for the reduced (a) borosilicate glass plate and (b) silica glass plate following electrolytic reduction at $0.9 \mathrm{~V}$ vs. $\mathrm{Ca}^{2+} / \mathrm{Ca}$ for 30 minutes in molten $\mathrm{CaCl}_{2}$ at $1123 \mathrm{~K}$. 
1 Fig. 8 XPS spectra for (a) B $1 s$ and (b) Si $2 p$ for the borosilicate glass samples before and after the electrolytic reduction at $0.9 \mathrm{~V} \mathrm{vs} . \mathrm{Ca}^{2+} / \mathrm{Ca}$ for 60 minutes in $\mathrm{CaCl}_{2}$ at $1123 \mathrm{~K}$.

4 Fig. 9 (a) SEM image of unreduced borosilicate glass. (b) SEM image and EDX maps for $\mathrm{Si},(\mathrm{Si}+\mathrm{O}),(\mathrm{Si}+\mathrm{Al}),(\mathrm{Si}+\mathrm{Cl})$ and $(\mathrm{Si}+\mathrm{Ca})$ of sample $\mathrm{B}-2$ reduced at $0.9 \mathrm{~V}$ vs. $\mathrm{Ca}^{2+} / \mathrm{Ca}$ for 30 minutes in molten $\mathrm{CaCl}_{2}$ at $1123 \mathrm{~K}$. (c) EDX analysis result for the unreduced borosilicate glass and the reduced borosilicate glass at point 1 and 2 indicated in (b). 


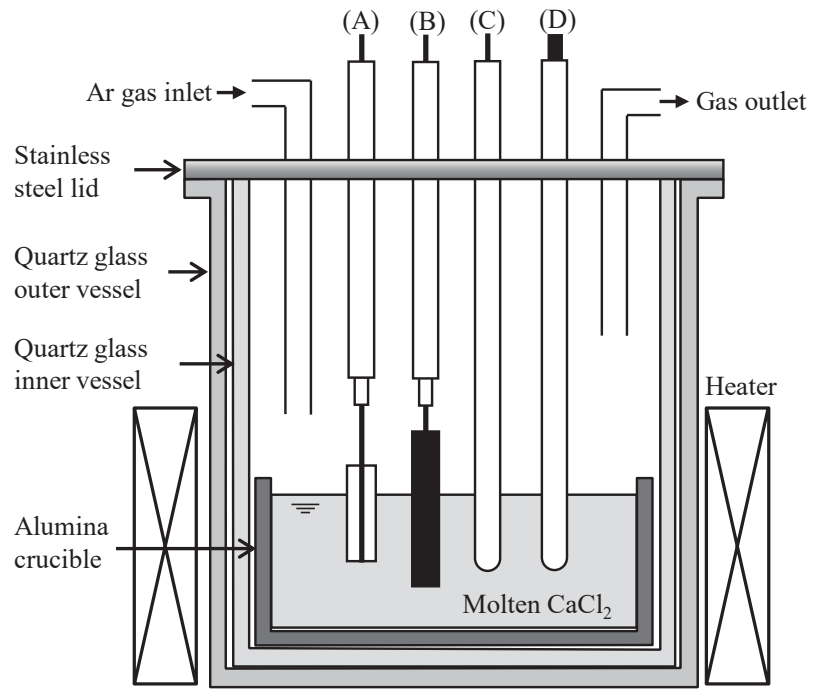

Fig. 1 Schematic of the experimental apparatus. (A) Working electrode, (B) graphite counter electrode, (C) Ag+/Ag reference electrode, and (D) thermocouple. 


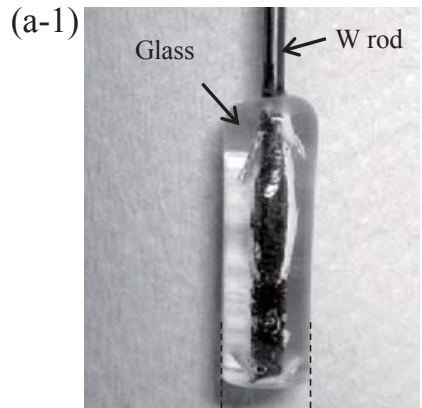

(b)

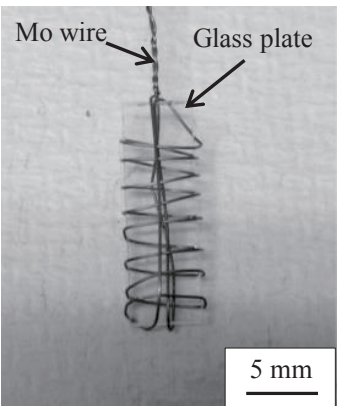

(a-2)

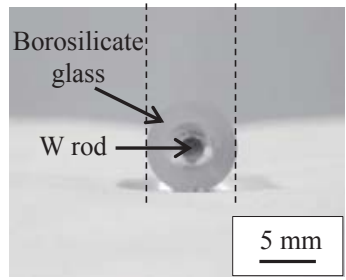

Fig. 2 Photographs of (a-1) the side view and (a-2) the cross-sectional view of a glass-seal electrode and (b) a wire-wound electrode. 
(a)

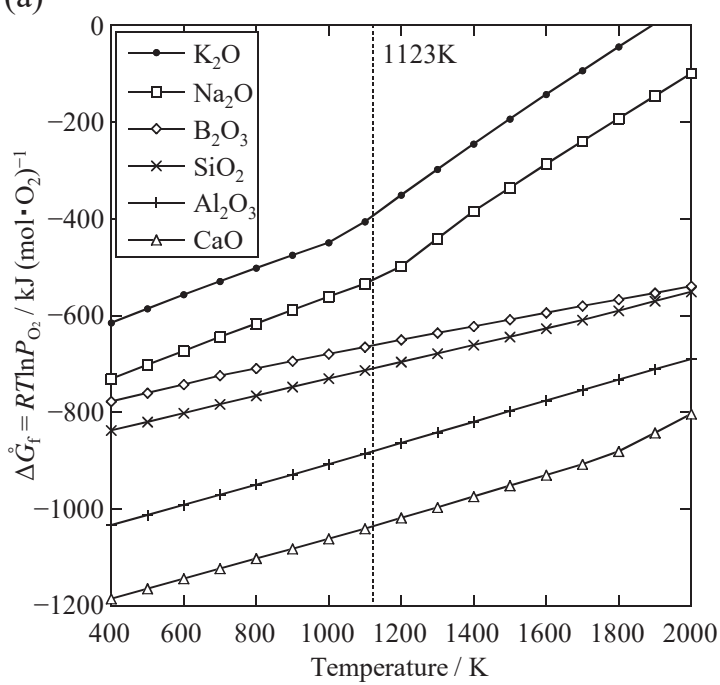

(b)

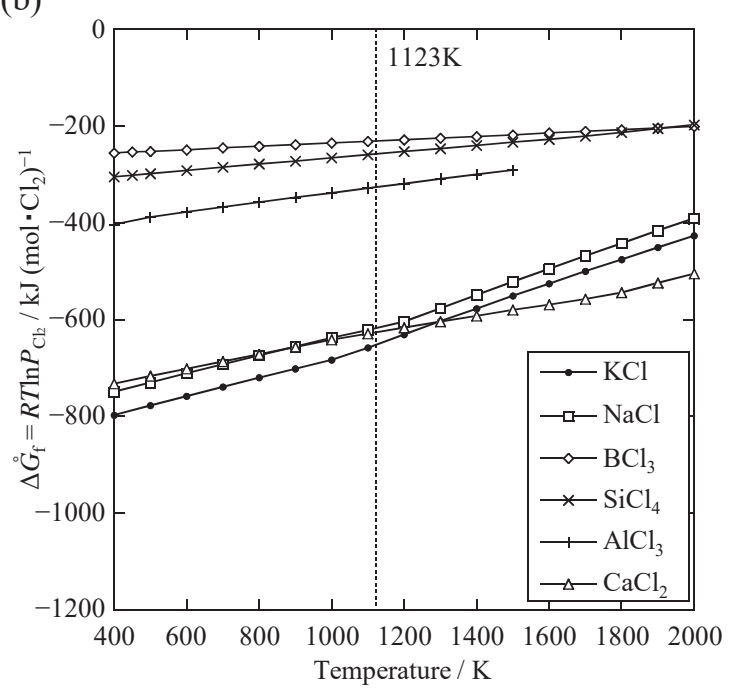

Fig. 3 Ellingham diagrams for selected (a) oxides and (b) chlorides ${ }^{46}$. 
(a)

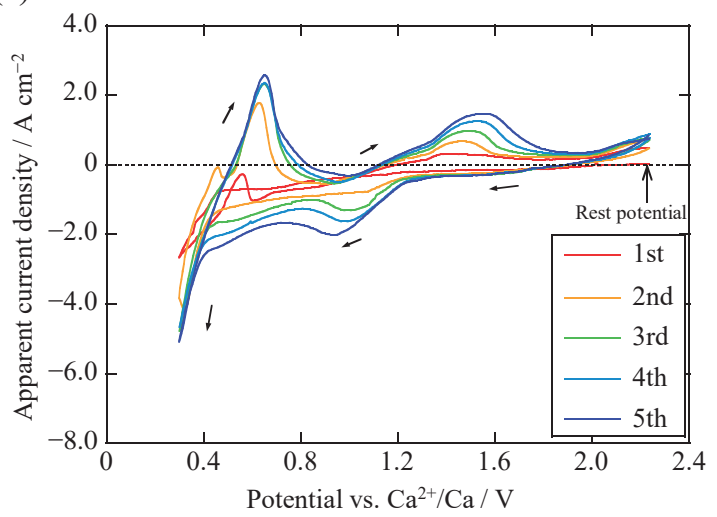

(b)

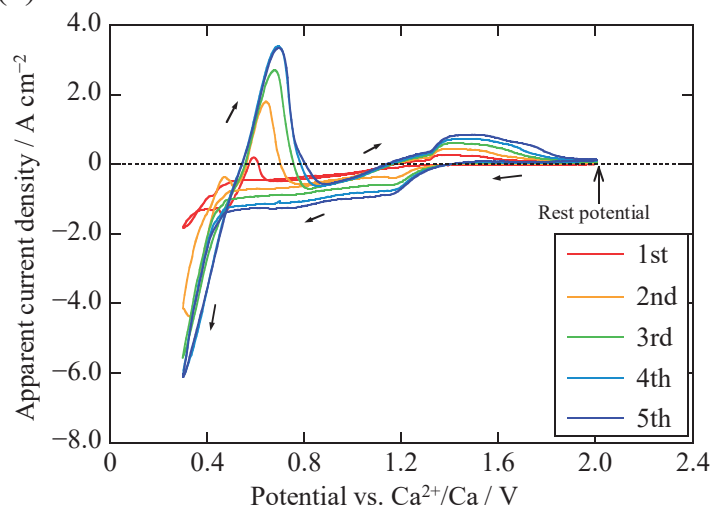

Fig. 4 Cyclic voltammograms for sealed (a) borosilicate and (b) silica glass electrodes in molten $\mathrm{CaCl}_{2}$ at $1123 \mathrm{~K}$. Scan rate: $100 \mathrm{mV} \mathrm{s}^{-1}$. 


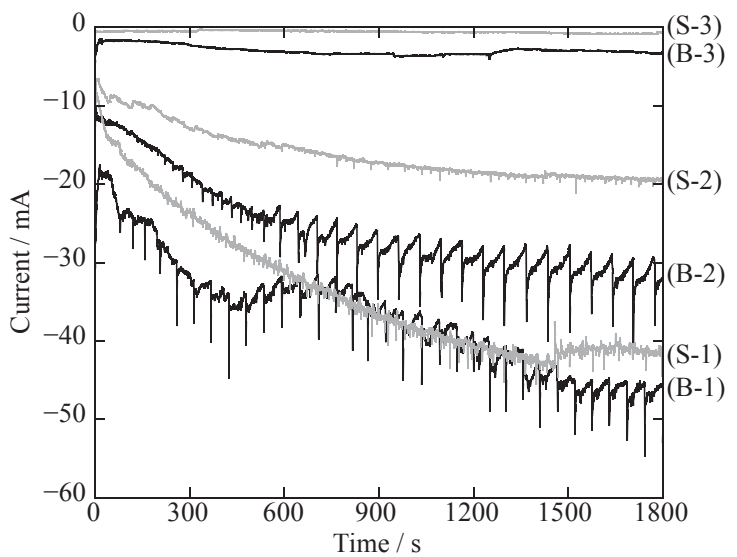

Fig. 5 Current-time curves during the potentiostatic electrolysis of the sealed borosilicate glass electrodes at (B-1) $0.6 \mathrm{~V}$, (B-2) $0.9 \mathrm{~V}$, and (B-3) $1.4 \mathrm{~V}$ and the sealed silica glass electrodes at (S-1) $0.6 \mathrm{~V}$ and (S-2) $0.9 \mathrm{~V}$ vs. $\mathrm{Ca}^{2+} / \mathrm{Ca}$ for 30 minutes in molten $\mathrm{CaCl}_{2}$ at $1123 \mathrm{~K}$. 
(a)

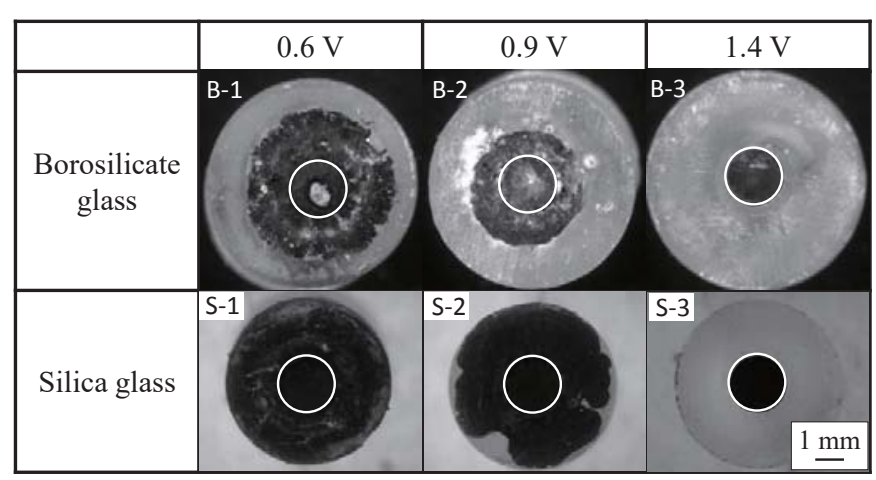

(b) Side view

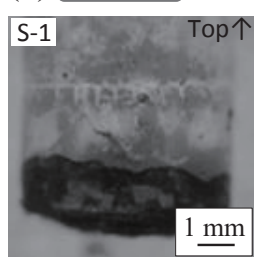

(c) Cross-section

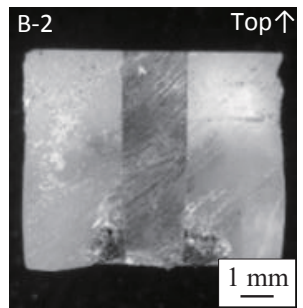

Fig. 6 (a) Microscope images of the sealed glass electrodes following potentiostatic electrolysis at $0.6 \mathrm{~V}, 0.9 \mathrm{~V}$, and $1.4 \mathrm{~V}$ vs. $\mathrm{Ca}^{2+} / \mathrm{Ca}$ for 30 minutes in molten $\mathrm{CaCl}_{2}$ at $1123 \mathrm{~K}$. White circle shows the boundary between the tungsten rod and the glass. (b) A surface side view of sample S1. (b) A cross-sectional view of sample B-2. 


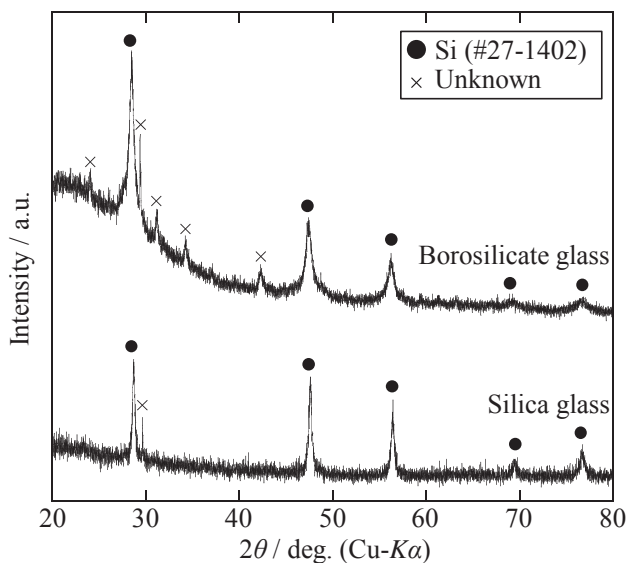

Fig. 7 XRD patterns for the reduced (a) borosilicate glass plate and (b) silica glass plate following electrolytic reduction at $0.9 \mathrm{~V}$ vs. $\mathrm{Ca}^{2+} / \mathrm{Ca}$ for 30 minutes in molten $\mathrm{CaCl}_{2}$ at $1123 \mathrm{~K}$. 

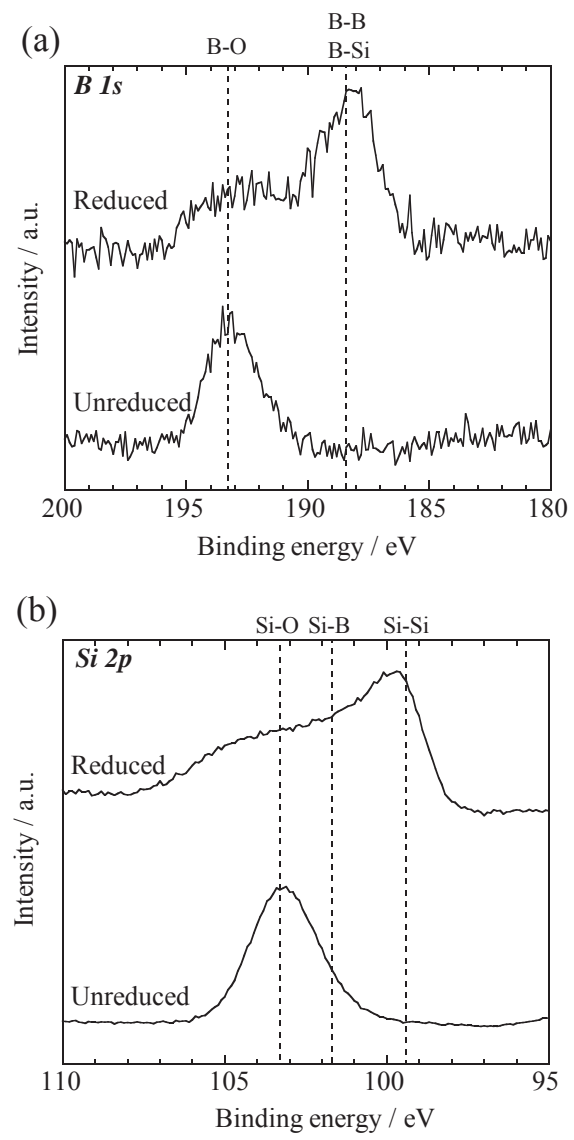

Fig. 8 XPS spectra for (a) B $1 s$ and (b) Si $2 p$ for the borosilicate glass samples before and after the electrolytic reduction at $0.9 \mathrm{~V}$ vs. $\mathrm{Ca}^{2+} / \mathrm{Ca}$ for 60 minutes in $\mathrm{CaCl}_{2}$ at $1123 \mathrm{~K}$. 
(a)

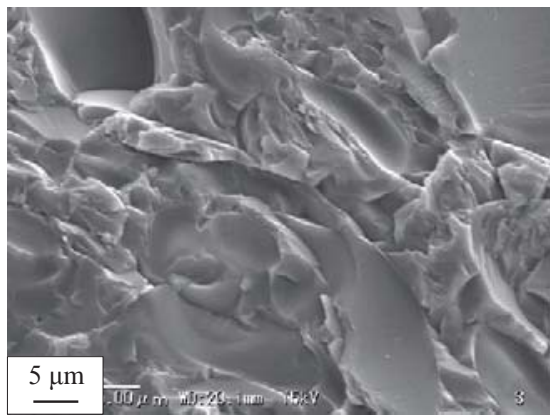

(c)

\begin{tabular}{c|rrr} 
& Unreduced & \multicolumn{1}{c}{ (1) } & \multicolumn{1}{c}{ (2) } \\
\hline $\mathrm{Si}$ & 34.66 & 92.28 & 10.31 \\
$\mathrm{O}$ & 60.55 & 5.72 & 53.97 \\
$\mathrm{Al}$ & 1.65 & 1.58 & 11.28 \\
$\mathrm{Na}$ & 2.87 & 0.42 & 1.00 \\
$\mathrm{Ca}$ & 0.28 & 0.00 & 15.10 \\
$\mathrm{Cl}$ & 0.00 & 0.00 & 8.34
\end{tabular}

(b)

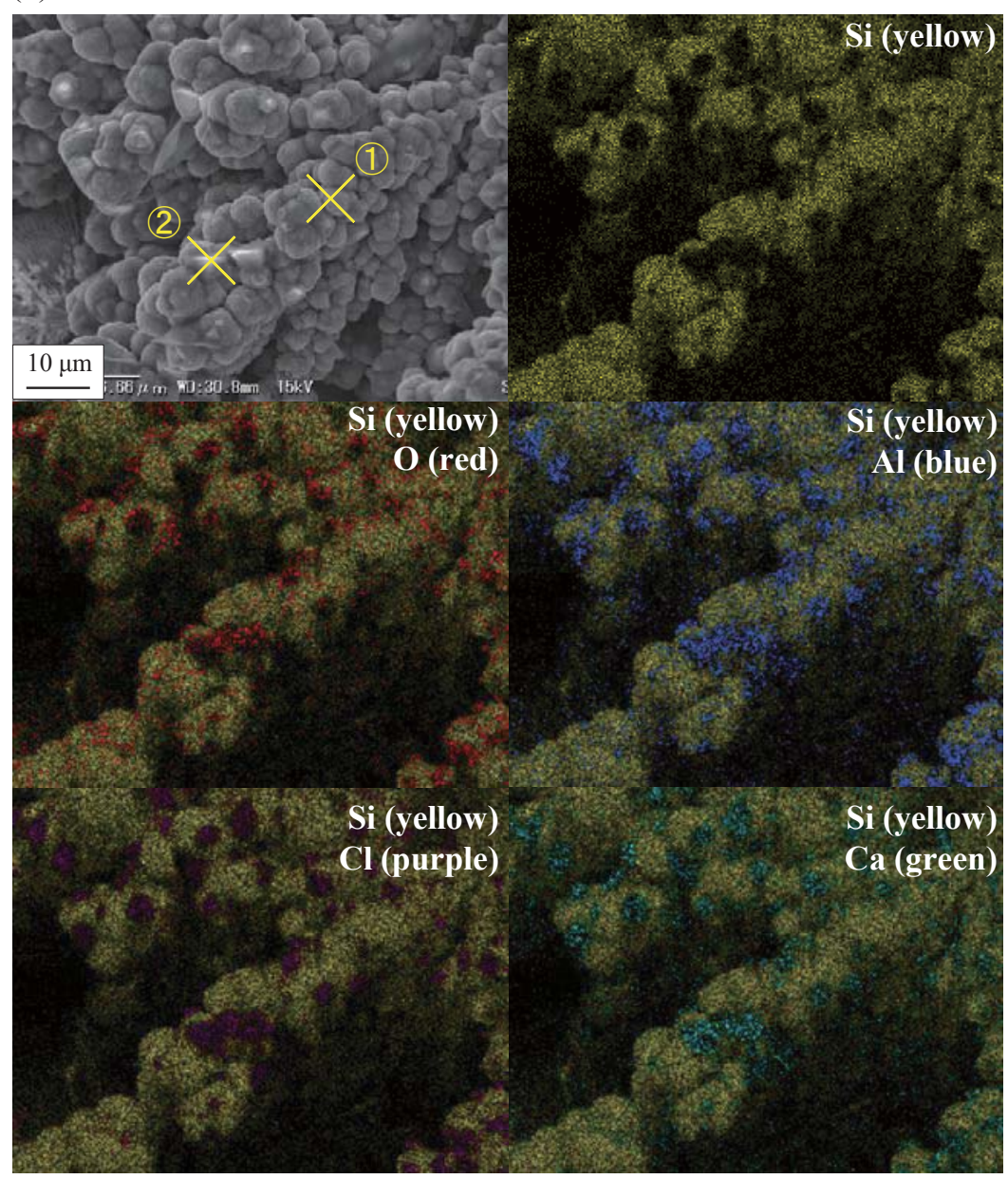

Fig. 9 (a) SEM image of unreduced borosilicate glass. (b) SEM image and EDX maps for Si, (Si + $\mathrm{O}),(\mathrm{Si}+\mathrm{Al}),(\mathrm{Si}+\mathrm{Cl})$ and $(\mathrm{Si}+\mathrm{Ca})$ of sample $\mathrm{B}-2$ reduced at $0.9 \mathrm{~V} \mathrm{vs} . \mathrm{Ca}^{2+} / \mathrm{Ca}$ for 30 minutes in molten $\mathrm{CaCl}_{2}$ at $1123 \mathrm{~K}$. (c) EDX analysis result for the unreduced borosilicate glass and the reduced borosilicate glass at point 1 and 2 indicated in (b). 